\title{
"NEW WAYS OF LIVING, AS OLD AS THE WORLD"1: BEST PRACTICES AND SUSTAINABILITY IN THE EXAMPLE OF THE ITALIAN ECOVILLAGE NETWORK
}

\author{
MARTINA LOSARDO \\ University of Milan "Bicocca" \\ Department of Human Sciences for Education \\ 20126 Milan, Piazza dell'Ateneo Nuovo 1 \\ m.losardo@campus.unimib.it
}

DOI: $10.17234 /$ SEC.28.3

Preliminary communication

Received: 14. 4. 2016.

Accepted: 12. 5. 2016

This article is an open access article distributed under the terms and conditions of the CC BY-NCND 4.0 license.

The ecovillage movement is an international network of intentional communities with a focus on social, economic, and environmental sustainability. Unlike other environmental movements, their struggle for achieving a more sustainable lifestyle includes efforts to enhance their living environment, based on the idea that humans are part of nature as any other living being. In pursuing this goal, they often recover traditional knowledge and practices rooted in a precapitalistic rural past, when, as they believe, the relations with the Other (community and nature as well) were more satisfactory than in contemporary industrialized society.

Keywords: ecovillages, community, sustainability, permaculture, rural past, neoruralism, nature

The process of providing for people's needs in more sustainable ways requires a cultural revolution.

(David Holmgren. 2002. Permaculture: Principles and

Pathways beyond Sustainability)

\section{INTRODUCTION ${ }^{2}$}

Over the last two decades, in the Western world, the insecurity of existence has ceased to be an exceptional and momentary landmark in

\footnotetext{
${ }^{1}$ This expression is taken from the motto of the Italian urban cohousing Numero Zero (Turin), and it refers to the values of sharing, conviviality, and solidarity that they consider lost in the contemporary industrialized society.

${ }^{2}$ I wish to acknowledge the help and support provided by Daniela Carpano and Anna Martini in restructuring this article. I would also like to thank Dave Hogan for the useful suggestions provided in revising the language.
} 
everyone and everyday life. Instead, it has become a cultural cypher of postmodern times, characterized by a vague and unpredictable world of liberalization, flexibility, competition, and endemic uncertainty (Bauman 2001).

A sense of global vulnerability has gradually expanded among civil society, and brought forth bottom-up answers to environmental and economic crisis, as well as to the sudden socio-cultural changes. New kinds of social movements have emerged, such as the Degrowth or Downshifting Movement, the Slow Movement, Community Supported Agricultures, Permaculture, and Transition Towns among others. They strive for a social change towards more sustainable lifestyles, whose tenets are cooperation, resilience, and local self-organization (Fox 2013). These movements go beyond street protests and direct political engagement to engage straight in alternative lifestyles, considering themselves examples and experimentations of this social and cultural change. Among the mentioned expressions of Western active citizenship, ecovillages represent a complete and radical alternative, since what is required of its members is a deeper and longer engagement. Indeed, life in an ecovillage implies embracing a whole new lifestyle, sharing housing, and moving in a rural context.

An ecovillage is an intentional community ${ }^{3}$ with a manifold approach to economic, environmental, and social sustainability. Sustainability is pursued everyday and in every aspect of daily life, by working on the relationship with the Other, be it other members of the group, living beings that share the same ecosystem, or nature itself (Svensson 2002). Tired and frustrated of fighting with a capitalist system with which they do not identify, ecovillagers counterpoise a concrete and renewed sense of community to the uncertainty characterized by liquid modernity (Bauman 2001). Nonetheless, they are not utopian enclaves out of touch with reality. One of their main purposes is to network with other local or international associations engaged in the same issues, proposing themselves as a core

\footnotetext{
${ }^{3}$ Intentional communities I refer to here denote the communities whose members deliberately and consciously choose to share their ways of life (including, but not necessarily, housing), and to orient them towards specific goals or sets of values (Lockyer 2007). These values are often translated and implemented as clear and effective alternatives to the dominant society (Ibid.).
} 
nodes of transition, and operating as living laboratories of social and educational experimentation.

The ecovillage movement can be considered the community part of the wider alter-global movement. It is globally spread, but takes different shapes in different contexts, as the ecovillages often restore local traditional knowledge and practices to better relate with the surrounding environment. The movement has a direct lineage from the development of historical communities, such as the hippie communes that arose from the American counter-cultural movement of the 1960s, or the European political experiments related to the French May of 1968. In addition, rural ecovillages can also be considered part of a global migration from cities to the countryside in search of the better quality of life that has existed since the emergence of cities.

In this article, based on ethnographic findings of an ongoing research, I discuss some successful sustainable solutions adopted by ecovillages in their daily lives. Although the movement also includes few urban settlements, I will focus on the rural experiences, as they are the most widespread and represent an overwhelming majority in my research area.

After a methodological premise, I will first trace the inception and history of what is today considered an ecovillage. Secondly, I will analyze the ecovillages' idea of sustainability, underlining variations of the concept inside and outside the movement. Thirdly, I will focus on meaningful ethnographic examples, showing how the ecovillage pursuit of environmental sustainability is influenced by a distinct idea of the relation between human activities and the surrounding natural world. Finally, I will discuss how the ecovillagers' idea of nature is connected with an idealized vision of rural past, and how these cultural resources are important in interpreting and overcoming the contemporary crisis. In the conclusions, I will stress the importance of anthropology dealing with these kinds of experimental practices in order to propose valid examples of better futures.

\section{METHODOLOGY}

This research is based on the qualitative data collected among the members of RIVE (the Italian Ecovillages Network), which is a member of GEN, the Global Ecovillage Network. RIVE was founded in 1996, to 
link existing local sustainable communities and support new ones. Today it represents most of the Italian ecovillages: sixteen proper ecovillages, eleven ecovillages under construction, and thirteen projects, ${ }^{4}$ mostly located in the central regions of the country (Tuscany, Umbria, Marche, Emilia Romagna, and Lazio).

I decided to conduct my fieldwork in my own country because Italy, like other South European countries (such as Greece, Spain, or Portugal) has been deeply affected by the recent global economic crisis. In this difficult context, ecovillages are increasing in number every year, implementing attainable, local solutions to otherwise overwhelming social, economic, and ecological problems observed worldwide. Following a multi-sited ethnographic approach, I spent the last two years attending the activities organized by RIVE and its communities. Since RIVE does not have a headquarters, the members take turn in hosting the events. This includes workshops, gatherings, open days, conferences, and assemblies. Therefore, it is the network, and not single communities, that is the object of my research. I made this methodological choice because I believe that RIVE is a "pragmatic knowledge community" where the supportive social environment and the low-impact way of life pursued by each ecovillage enable unity in broader diversity (Liftin 2009:125).

According to an engaged approach, I am an active volunteer of the association myself, and a member of the communication support group. Through these activities I have had access to closed meetings and I could interact and familiarize with some of the key members of the national movement.

In this setting I conducted twenty formal interviews and dozens of informal ones among board members, founders, spokespersons, ecovillagers, allies, and supporters. Furthermore, I analyzed the interconnections between the ecovillage and the permaculture movements by attending courses

\footnotetext{
${ }^{4}$ According to RIVE basic agreements, an ecovillage is a community that has existed for at least two years and is composed of at least five unrelated members who share fundamental values and live together intentionally. An "ecovillage under construction" is a community that is in the process of acquiring this status, while an "ecovillage project" has the intentionality but does not yet have a place or a consistent group to create a community.
} 
organized in different communities and by distributing a questionnaire among the participants. Then I spent six months in two specific ecovillages with high involvement within the network. Here I conducted participant observation to better understand the practices behind the values officially declared by the network. The first one is Habitat, an ecovillage under construction and a permaculture project in the middle of the Tuscan hills, whose main purpose is to study, develop, and protect the local vegetable and animal genetic resources (Habitat Manifesto). The second one is La Città della Luce (The City of Light), an ecovillage of twenty-five members in the region of Marche, whose main interest is conducting research and education in the field of holistic disciplines. ${ }^{5}$

During my fieldwork and my interviews, I focused on how some concepts (such as nature, home, sustainability, network, tradition) were lived and interpreted, what they meant for those who expressed them, and how they were reflected in everyday practices and behaviors. Lately, following a grounded theory approach, I realized that some analytic categories arose from the fieldwork more than any others. These categories, related more to feelings of belonging, commitment, and awareness than to the ecological statements, are guiding my current analysis of the phenomenon.

\section{DEFINING AN ECOVILLAGE}

The very first definition of an ecovillage describes it as:

A human scale, full-featured settlement, in which human activities are harmlessly integrated into the natural world, in a way that is supportive of healthy human development and can be successfully continued into the indefinite future. (Gilman 1991)

According to Robert Gilman, one of the pioneers of the movement, a "human-scale, full-featured settlement" is a small village where members know each other and can influence the community's direction. In addition, there is a balance of the elements that constitute normal living: residence,

\footnotetext{
${ }^{5}$ Holistic disciplines encompass all the arts, sciences, philosophies, techniques, and therapies concerning health, wellness, inner and spiritual research that consider human beings in their wholeness (www.olisticmap.it).
} 
food provision, work activities, education, healthcare, leisure, and social life (Ibid.).

This way of life implies nostalgia for some features of past and traditional forms of rural life, such as closer relations, solidarity, cooperation among neighbours, active engagement within the community, and a balance with natural cycles.

This, though, as stressed by Gilman itself, is at odds with three realities of modern ecovillages. Firstly, this nostalgic picture of bucolic bliss is highly idealized. Even if there is much to be learned from traditional rural villages, historically it has been proved that they were neither supportive of healthy human development, nor examples of harmony between humans. Secondly, ecovillages do look back at an idealized past, but are shaped by modern concerns, such as the environmental crises, the challenge of new technologies, and new levels of awareness about global interconnections. Thirdly, the balance with the natural environment in small rural settlements often depends on their low population density, while they use forms of agriculture that are quite destructive to the environment.

Instead, the goal of ecovillages is to create an efficient and selfsufficient microcosm of "best practices" that may serve as an example for larger settlements too. Hence, the "village" here is a symbolic compendium of the values pursued within the movement and associated with tradition and rurality.

Gilman's definition itself continues to be controversial. It has been criticized for lacking spiritual and social dimensions (Jackson 1998), and has been seen as a description of an outcome rather than a strategy for its realization (Dawson 2013).

What is commonly agreed upon is the recognition of a great number of realities worldwide with common aims, purposes, structures, and needs, striving to achieve a more sustainable lifestyle. In this regard, the idea of a network for sharing knowledge and practices began to emerge in the 1990s. A series of international meetings between community members were organized to discuss strategies, to develop a common definition of ecovillage, and to formalize the network (Bates 2003). The process led to the creation of the Global Ecovillage Network (GEN) in 1994.

More than twenty years later, GEN has a consultative status in the area of sustainable development at the United Nation's Economic and Social 
Council and represents most of the sustainability-oriented communities worldwide. It includes more than 13,000 members among ecovillages, permaculture projects, and other eco-settlements (Lockyer 2007). The members are divided into five continental sub-networks and a transnational working group focused on the youngest, called NEXT-GEN.

\section{PURSUING DIFFERENT INTERPRETATIONS OF SUSTAINABILITY}

Even though "Connecting Communities for a Sustainable World" is the GEN motto, the exact meaning of "sustainability" has yet to be defined. It can take different shades according to times, disciplines, paradigms and the aim it serves. Sustainability can be an ideology, a life-style, a way of consuming and producing, or a political and economic strategy.

Based on the importance attributed to the conservation of nature, two main forms of sustainability can be defined: a weak and a strong sustainability. Weak sustainability focuses on guaranteeing the integrity of a "potential welfare" to next generations (Pearce and Atkinson 1993). In this utilitarian approach, natural and manufactured capitals are considered interchangeable due to faith in technological progress. On the other hand, strong sustainability implies an ecocentric approach, which states that the whole stock of natural capital should be kept intact. From an ethical point of view, the main difference between the two approaches is the way in which they view nature: it is an instrument in the former, and a value per se in the latter.

The ideal of justice and the importance of all forms of life expressed by ecovillages indicate a "strong sustainability" approach. Indeed, sustainability in the ecovillage view "brings with it a profound commitment to fairness and non-exploitation - toward other parts of today's world, human and non-human, and toward all future life" (Gilman 1991).

The ecovillage movement conceives sustainability both economically, ecologically, and socially, as the Brundtland Report requires. ${ }^{6}$ The European Commission (EC) bases its concept of sustainability on the Report as well,

\footnotetext{
6 "Our Common Future", also called "The Brundtland Report" after the former minister of Norway who directed the works, was published by the UN World Commission on Environment and Development in 1987. The goal of the Commission was to propose
} 
considering "social, economic and environmental issues as inseparable and interdependent components of human progress". In addition, as reported in its webpage about sustainable development, the EC affirms that "sustainable development will not be brought about by policies only: it must be taken up by society at large as a principle guiding the many choices each citizen makes every day" and that "this requires profound changes in thinking, in economic and social structures and in consumption and production patterns".

Though ecovillages can be considered an example of what the European Union has described as a goal of sustainable development, there remain differences in the application of their ideas of sustainability.

The primary distinguishing feature of ecovillages from other sustainability-oriented realities is reflected in the methods by which they pursue a systemic and synergistic approach to the elements of everyday life. Ecovillages ultimately strictly link the environmental and economic concerns of their own land to a deeper relation with the local environment itself, including relationships inside the community, the preservation of the local biodiversity, and the consideration of local traditional wisdom. There can be many farms, associations, or cooperatives more successful than ecovillages in achieving their sustainable goals, but "what makes ecovillages unique and relevant is how they are putting these pieces together into wholes that are greater than the sum of their parts" (Greenberg 2013).

Furthermore, according to the "Community Sustainability Assessment" (CSA) developed by GEN, the economic sphere does not stand for one of the sustainability pillars, but it is integrated and dependent on the environmental one. Therefore, more sustainable ways of food and resources provision, production, distribution, and consumption are included in the environmental goals.

It is the spiritual sphere that becomes the third indispensable pillar to achieving a holistic and long-term sustainable society. ${ }^{7}$

long-term environmental strategies to reach a "sustainable development", defined for the first time as "the kind of development that meets the needs of the present without compromising the ability of future generations to meet their own needs. (Edwards 2005).

${ }^{7}$ According to the CSA, the spiritual sphere encompasses all religions and spiritualties, common visions and values, arts and leisure, rituals and celebrations, harmony and quality of life inside the community, peace-building in the world, and a "growing understanding of the interconnectedness and interdependence of all the elements of life on Earth". 
Finally, the concept of sustainability has itself been questioned: Alfredo Camozzi, member of La Comune di Bagnaia ecovillage, former president of the RIVE, and current member of its board, related to me during an interview that some prefer the term eco-reversibility:

"I don't like the idea of sustainability... because airports and skyscrapers are also sustainable. ... First of all we have to understand what is sustainable compared to what: since we human beings ... have contributed to the reduction of nature's reproducing ability, we have modified it in a destructive way; to say that an activity must be eco-sustainable is like saying that it must be sustainable with respect to the level of destruction reached by nature. We use another term: eco-reversible. Therefore, we must be able to give back to nature and, at the same time, to return more than we have consumed from nature. $\ldots$ This is the real point of divergence, where our life inevitably clashes with the present socio-economic system that is going in a totally opposite direction."

In this view, the ultimate goal to be achieved by every ecovillage and network should be the creation of an alternative social system, based on a massive, widespread, and ongoing change in the lifestyle of all human beings. The first aim must be to diminish environmental impacts and to leave future generations a better world. Improving instead of just conserving the environment is what makes the ecovillage movement the cultural space for the emergence of a new radical environmental paradigm (Kasper 2008:12), where Man is no longer seen as the "Lord and Master of Nature" as in the mechanistic vision of the capitalist system, but instead the human-nature relation is valued in itself (Guidi 2010:86).

Those who believe that sustainability as pursued by institutions (national governments, $\mathrm{UN}$, and EU) is not enough, typically belong to the "very strong sustainability" approach, generally called "deep ecology". Deep ecology is an environmental philosophy that rejects the dualistic view of humans and nature as separate and different, believes in nature's intrinsic value, and tries to follow natural rhythms and examples instead of working against them (Pepper 1996:17-19).

This is one of the most indicative differences between the holistic attitude of such movements as the ecovillage movement, and 
the institutional approaches to sustainability and the environment. For example, the European Union believes that environmental policies should principally "protect nature, and safeguard the health and quality of life of people". EU also believes that "protecting the environment and maintaining a competitive EU presence on the global market can go hand in hand" ("Environment" in Topics of the European Union).

Much like the Degrowth movement, ecovillagers think that if we consider development to be the same as the capitalistic pursuit of unlimited economic growth without recognizing the limits of natural resources, then sustainable development is an oxymoron. Ecovillagers believe that this greenwashing of the concept of development is deliberately used to appease the conscience and as 'a strategy for sustaining 'development', and not to support the flourishing and enduring of an infinitely diverse natural and social life." (Esteva 1991:13). Therefore, ecovillagers "recognize the need to identify 'sustainable life practices' which go far beyond simply substituting conventional inputs and practices without altering the fundamental orientation of the bigger system" (Castrejon 2007:29).

\section{EXPERIMENTING: BEST PRACTICES IN SUSTAINABLE LIVING}

In their everyday life, ecovillagers particularly work on environmental sustainability. Conscious of the human and environmental costs of global production, consumption, and waste, they try to make the outsourcing visible by changing their habits and localizing these processes.

Their sustainable solutions are connected with a specific idea of the relationship between man and nature that contributes to frame the international network as an original and organic movement with a specific identity. Nonetheless, every community decides which practices are the most suitable to reach the goal of a more sustainable lifestyle. Their choices depend on where the community is located, how it is morphologically structured, how many members it has, and what its focus is (spiritual, political, agricultural, etc.). Despite these differences, most of them apply permaculture, a holistic system of design based on direct observation of nature. Permaculture uses both the wisdom of traditional way of cultivating as well as the modern scientific and technological knowledge (Lockyer and 
Veteto 2008) to create sustainable human settlements. The permaculture and ecovillage movements share some core values, like the respect for natural cycles, the richness that diversity brings both in biological and cultural contexts, or the principle of equality between humans and other forms of life.

In this section, I will discuss the practices employed on the ground which have arisen most often during my fieldwork participant observation, highlighting their importance in pursuing a sustainable living.

\section{Food Practices}

By growing their own food and by attempting to achieve selfsufficiency, ecovillages reduce their ecological footprint in many ways: they do not use pesticides; they eat fewer meat and dairy products (as the meat industry is one of the major cause of global warming); they do not participate in the food long chain, preferring and supporting "kilometre zero" production; they avoid mass consumption based on unhealthy and unethical reasons.

An orchard and/or a horticultural garden can be found in every community. It is primarily intended for self-consumption, whereas the surplus is sold at local farmers' markets or through GAS (solidarity purchase groups, the Italian version of Community Supported Agriculture, Grasseni 2014). Organic, biodynamic, and synergistic are the most common forms of agriculture, because they are respectful of the land's needs, the traditional crops, and local biodiversity. ${ }^{8}$ The main objective is making the use of any chemical fertilizer unnecessary, because, as the creator of synergistic gardening Emilia Hazelip believes, if left to its natural state the cultivated soil will react as the wild one (Hazelip 2014).

The seeds that they use are obtained outside the market, to avoid the risk of using genetically modified species. They are exchanged at seed fairs or

\footnotetext{
${ }^{8}$ Among them, synergistic gardening is the most widespread, as it fits with the ecovillage ethic of human-nature balance and with its holistic approach. It consists of a form of cultivation where different species in natural consociation are densely planted without turning over the land, and then covered with mulch that imitates the natural layer of leaves and compost.
} 
provided by University departments that study heirloom and native species. In this way, ecovillages also contribute to safeguarding, regeneration, and the perpetuation of the local biodiversity, while contrasting corporate hegemony.

Regarding irrigation, rainwater is stored or traditional techniques of catching the moisture are applied, like the African clay pot method experimented at Habitat ecovillage. This method consists of burying a pot in the garden and filling it with water. Due to the porous nature of clay, the water seeps into the soil and is absorbed by plants by way of osmotic pressure.

Finally, the remaining basic needs are met through local, organic, and ethical producers or GAS. Some bigger communities, like La Città della Luce, have also created their own GAS, thus becoming the cornerstone of the bioregional best practices exchange.

\section{Housing practices}

The same kind of integration into the local natural and cultural environment is expressed by architecture. The majority of settlements I visited opted for dwelling solutions in harmony with the surrounding landscape, both regarding shapes, materials, and historical evolution.

Some communities, like Torri Superiore (Liguria), Upacchi or Campanara (Tuscany), have settled in abandoned hamlets, renovated to maintain the ancient structure intact. In this way ecovillages also counter the general tendency of depopulation in semi-abandoned rural regions, and their consequential social and economic marginalization. In fact, "in Italy, due to the relatively low cost of land and buildings as well as almost complete isolation from the mainstream world, many ecovillages have been developed in less productive areas" (Giani 2011:19).

Other ecovillages have experimented with different types of semimobile solutions to be integrated as much as possible with the surrounding landscape, or at least not to be obtrusive. For instance, in Il Giardino della Gioia (The Garden of Joy), an ecovillage in Southern Italy set in an olive tree grove, the members live in yurts, a modern adaptation of the circular tents on stilts used by nomadic people in Mongolia. In Campanara, a community 
settled in the mountains between Tuscany and Emilia Romagna, the members live inside the church of an abandoned village, and accommodate guests in a Native American tepee. In Habitat there are very few constructed structures, and the members sleep in caravans or tents.

Constructions and restoration are usually self-made, adopting ecological techniques and materials in accordance with traditional local building knowledge. For instance, municipality would give Habitat adjacent land for free as long as they restore the ruins with traditional techniques.

Finally, there are new projects of ecovillage, like La Corte del Vento (The Court of the Wind) in Veneto, where all the houses are thought to be self-constructed with traditional techniques and local materials, like straw, wood, or mud bricks. Self-construction also implies more ecologically efficient buildings, as they limit energy dispersion and facilitate living off the grid by using alternative energy resources.

\section{Other sustainable practices}

Food and housing are the most important and common aspects of everyday life where sustainable practices are experimented with. Nevertheless, ecovillagers try to be sustainable in many other ways. For instance, they try to self-produce as many primary goods as they can, through bread-making, soap making, pruning, sewing, pottery, herbs identification and medical uses, etc. In this way, they are renewing and perpetuating traditional crafts, saving money, reducing waste by reusing and recycling, and avoiding unhealthy and unethical consumption.

Consumption is another aspect in which ecovillagers try to steer toward more sustainable ways of dealing with the environment. They try to minimize their ecological impact by composting, buying in bulk, repairing and recycling objects, sharing facilities, or saving resources like water and energy. Panta Rei, an ecovillage and centre for education on sustainable development on lake Trasimeno, with its semi closed water system is a case in point. The system relies on cisterns that collect rainwater to be used for washing machines and for the heating, while all the wastewater is depurated using degreasers and phyto-purification (Panta Rei member, e-mail to author, February 25, 2016). This depurated water is used for irrigation and toilet flushing, saving more than $50 \%$ of the drinking water, which comes directly 
from a pure spring nearby (from "Panta Rei: l'ecologia che scorre", Terra Nuova website). Other ecovillages save water also by using composting toilets and pipi-ponics, dry toilets self-constructed with recycled materials where human excrement is composted and used as organic fertilizer.

Concerning electricity and fossil fuels, each community has its own way of saving resources while reducing pollution: in La Città della Luce the members share only few cars with a reservation system; in the small Tuscan ecovillage of Corriceli there is a pedal-powered washing machine; in La Comune di Bagnaia, an old commune converted into an ecovillage, heating is provided by solar panels and by a gasifier stove boiler fuelled by biomass, while photovoltaic panels cover nearly two-thirds of the energy required (Guidi 2010). Finally, Il popolo degli elfi ("The Elves People"), one of the oldest and largest communities in Italy, can be considered the most extreme example of anti-consumerist choice of life, where some "live in houses without electricity and without any urban comforts, heated with wood and lit with candles.” (Olivares 2009).

\section{MOVING INTO THE WOODS AND INTO THE PAST}

Notwithstanding the efforts to connect the most advanced scientific and technological solutions with local and traditional knowledge and skills, as the examples above show, this integration is still debated within the ecovillage world. A sort of neo-luddism (Wight 2008), in which all technologies considered harmful for the environment, human health, and social relations, coexists with the most advanced, alternative, and ecofriendly technologies of construction and provisioning of resources. At the same time, an idealized need for going back to the roots and perpetuating the traditional wisdom is accompanied by the necessity of cosmopolitism and openness to the new.

My hypothesis is that ecovillages overcome these contradictions by serving as a sort of selective historical memory container, where only the traditional knowledge and practices with a holistic approach to human and natural issues, and consequently with a minor impact on the natural environment, are preserved. To invent something has never been the ecovillages' objective. On the contrary, their efforts to join old ideas with old practices in a new way are quite evident. Indeed, the philosophies 
and practices of permaculture that ecovillages applied are explicit recombinations of traditional and ecological knowledge from various cultures presented in a systematic, holistic fashion (Whitefield 2012).

Among ecovillages' practices, some are source of curiosity and amusement for their rural neighbours. For example, Habitat members are called by the old local farmers "the guys who cut the grass using chickens" for they have built some "chicken tractors", mobile chicken coops to clean the field while at the same time feeding the hens. ${ }^{9}$

Other alternative options are even taken into consideration. During a permaculture introduction course at Panta Rei for example, a teacher told us that an old neighbour, after he had seen the results of mulching with straw to protect the plants from bad weather, began to do the same thing.

Nevertheless, there are some practices that were too big a challenge for what people already know and have learned about the land to be accepted. Attitude to weeds is an example. Anthropologist Guntra Aistara (2013) studied the reactions of Latvian organic farmers to the permaculture habit of not weeding, and observed that the practice is beyond acceptability for them, because it is not a part of local traditional agriculture or the farm modernization required by the EU regulations. Weeds, which are seen by both conventional and organic agriculture as an affliction, are a great source of biodiversity for permaculture. Their constant incursion into cultivated fields represents the proliferation of nature-cultural hybrids, whereas the creation of neat, weed-free fields represents an act of purification, the maintaining of order and neatness that is the symbol of modernity. ${ }^{10}$

These kinds of responses from the outside world are deeply connected with the ecovillage idea of human-nature relationship, one of the topics that best identifies and thus distinguishes the movement as an alternative example of society. Nature is seen as wild, free, divine in the broadest sense of the word, and man can only respect it as an equal and try to imitate it.

\footnotetext{
${ }^{9}$ Chicken tractor is a typical permaculture solution that encompasses two of the central permaculture principles: "each element performs multiple functions" and "each function is supported by many elements" (Mollison and Slay 2007).

${ }^{10}$ In her analysis Aistara follows Latour's distinction between purification and translation as the two main processes that form modernity, and argues that permaculture can be understood as a conscious and explicit creation of nature-culture hybrids.
} 
For this reason their gardens look like jungles, and their houses appear as shacks: every human activity is conceived and built so as not to interfere with the natural environment (Gilman 1991).

Their vision contradicts the Genesis-based idea that Man is the Lord of all the living beings and should rule and control them. It clashes even with the softer environmental statement that Man should protect nature. Even without a spiritual orientation, this vision of nature reigns supreme in every speech I heard among ecovillagers, so I argue that this is the most common cultural vehicle to carry on a counter-cultural view of what constitutes not only a healthy and sustainable lifestyle but also a just and balanced one. This is why some people decide to move to the countryside to fund or join a sustainable community. They believe that pursuing sustainability in the city is not enough to bring a real societal change, since only rural life can enable the holistic engagement with the natural world that this transition needs.

A counter-urbanization trend has existed since the emergence of cities, led by the will to escape from the confusion and frenzy of urban spaces in search of reassuring peace that the countryside can provide. Nonetheless, for centuries the city-country relationship has been marked by a depopulation of the smallest rural villages in exchange for the urban contexts. Only in recent decades has a bigger and more specific opposite movement appeared, strongly inspired by counter-cultural ideas (Halfacree 2006). ${ }^{11}$ It consists of people leaving the city for the countryside in search of a deeper contact with nature and the fundamental human needs, in order to lead a more complete, peaceful, healthy, and eco-friendly life. Ecovillages can be considered the spearhead of this movement, as they integrate the return to the land by way of creating small communities to provide experimental alternatives for the whole society. The majority of ecovillagers belong to the urban middleclass with quite a high level of education and very little knowledge about rural life and work. They consider rurality as the "repository for ways of life which are regarded as more natural, holistic and harmonious" (Rapport and

\footnotetext{
${ }^{11}$ Sociologists and geographers have at different times defined this kind of selective migration as neoruralism (Hervieu and Léger 1983; Nogué 1988), amenity-led migration (Osbaldiston 2012), back-to-the-land movement (Jacob 1997; Halfacree 2006), or counterurbanization (Boyle, Halfacree and Robison 1998; Escribano 2007).
} 
Overing 2000:315). Their vision is very alike to the academic discourse of the rural idyll, where the countryside is "pictured as a less-hurried lifestyle where people follow the seasons rather than the stock market, where they have more time for one another and exist in more organic community where people have a place and an authentic role." (Short in: Halfacree 1995:3).

As some scholars have stated, the Arcadian view of nature built around the concept of rural idyll is usually of urban origins (Horvadas and Stamou 2006). Therefore, ecovillagers" "return to the land" should be called the "resort to the land", since the countryside is idealized as a symbolic strategy to oppose the economic crisis, pollution, stress, and everything that is considered wrong in the urban lifestyle (Nogué 1988). "Symbols of the 'past' mythically infused with timelessness", often work as "condensation symbols", in which norms and values "become saturated with emotion, while the gross and basic emotions become ennobled through contact with social values" (Cohen 1985:102). Moreover, they usually "attain particular effectiveness during periods of intensive social change when communities have to drop their heaviest cultural anchors in order to resist the currents of transformation" (Ibid.).

According to my preliminary investigations, the country and the land seem to be the spatial contexts from which the ecovillagers' forebears emerge to help them with facing and overcoming the present's concerns. Indeed, in the specific case of the Italian ecovillage, the countryside is not just a symbolic resource, as they often recover family traditions, memories, and properties rooted in the peasant past. That is why I argue that these intentional communities cannot be considered traditionalistic, since they do not try to keep the past alive, but rather use it in a selective way to cope with the present (Ibid. 99). However, further investigations to prove this hypothesis remain to be done.

\section{CONCLUSIONS: NETWORKING}

Ecovillages are one of the responses that civil society is expressing in reaction to the contemporary economic, environmental, and social crisis, in conjunction with the weakening of trust in the established institutions that embody the representative democracy and the global market. Identifying the number of ecovillages in the world can be difficult, due to the vague 
definitions, few specific studies, sometimes isolation, and the dynamism of the movement. Nonetheless, the ecovillage network is a growing international phenomenon warranting increased attention. ${ }^{12}$

Attending ecovillages over the past two years I came to realize that the ecological concerns, although the movement represents them as the main reason to engage with this way of life, are secondary compared to the social need for participation, belonging, and sharing that drives people to leave their previous lives. The wish for being a part of something bigger is not only the main reason to join a community, but also the best resource the movement has. Indeed, encouraged by the feeling of not being alone in this fight for a better life, single members, communities, and networks of ecovillages are creating and inspiring connections with and among their surrounding environment, other local and international associations, rural and urban population, as well as producers and consumers. The ability to bring together realities with very different features, including spiritual communities, Marxist communes, agricultural cooperatives, holistic schools, etc., is one of the biggest achievements and major strengths of the international network. The so-called "biodiversity of experiences" that the members acquire is valued as a great resource for surviving within a network of experimental realities placed in very different environmental contexts. Their strategy seems in line with the article 1 of the UNESCO Universal Declaration on Cultural Diversity: "A source of exchange, innovation and creativity, cultural diversity is as necessary for humankind as biodiversity is for nature".

As a consequence of this ability to interconnect, not only have several ecovillages become or are becoming "federations of communities" (as in the Italian example of Damanhur and La città della luce), but they are also more and more central to the process of safeguarding, developing, and integrating the biocultural diversity (Maffi 2005) on their own local territory.

This shift from isolation and mutual suspicion to formal and informal alliances with the outside world is recent in the history of intentional communities, and it is more related to changes in the wider society than to

12 This fact is further demonstrated by the increasing number of MA theses and PhD dissertations on the topic (for a partial review see Andreas and Wagner 2012). 
conscious efforts made by ecovillages themselves (Dawson 2013:217-218). These collaborations involve conscious citizens, other organizations with similar values and visions, and even central or local government institutions (Ibid.). In fact, "concerns that not so long ago were limited to the margins of society - including healthy organic food, child-centred education, complementary medicine, meditation, and lifestyles based around lower levels of consumption - today attract interest in many sectors of society" (Ibid. 226).

Nowadays, educational programs, trainings in leadership skills and conflict facilitation, academic courses and research projects, participation in government or grassroots initiatives to safeguard the commons, or actions to spread knowledge about sustainable technologies, are regular activities that ecovillages organize or host in their local areas. Therefore, sustainable communities today are not romantic escapes from modern society, but concrete expressions of the need to foster a new relationship with the surrounding human and natural environment that an increasing part of the population in the West is feeling. They give concrete examples of good life, taking inspiration from different ideas of well-being that ancient or contemporary societies have developed, and modifying them according to their local biocultural environment.

In conclusion, in this paper I tried to give an overview of the needs and solutions for these needs as they are reflected in the ecovillage movement within the Western societies. They may still be a few examples representing a social transformative power, and one could argue that environmental and social problems have only worsened since the rise of the movement (Liftin 2009:141). Yet, what is relevant in studying the ecovillage phenomenon is the demonstration that it is possible to reduce one's own material consumption while enhancing the quality of life (Ibid.).

This is the reason why I believe that collaboration with the ecovillage movement should be encouraged in building a solid anthropology of the future (Appadurai 2013). As the paper briefly shows, there are several interesting questions that ecovillages could raise for anthropology, such as: new perspectives on the nature/culture dichotomy; the interpretation of tradition in connection with the hegemony of technological innovations; the holistic approach in dealing with one's own environment; the way 
some concepts such as privacy, community, and family are performed and perceived; and so on.

Anthropology has always had a strong relationship with marginal and counter-cultural perspectives. Furthermore, since it has become a post-colonial discipline, it has always borne witness to the injustices and inequalities in the political and economic relations between central and peripheral areas of the globalized world. Now it is time to focus on solutionoriented rather than problem-oriented approaches, taking advantage of the huge ethnographic literature about the human-nature relationship as well as of the well-rooted capacity for cultural critique that the discipline has developed.

We need to consider the "capacity to aspire", to have hope, to imagine a specific idea of "good life" as a cultural and collective fact, strongly related to local systems of values, meanings, communication, and dissatisfaction (Ibid.). Italian ecovillages represent a locally grounded and culturally oriented possibility of a good life. They are often based on essentialized assumptions that mix different cultural traditions together in a blurry cauldron, but they have the merit of proposing solutions to some of the most concerning environmental and social problems of the modern society, and giving valid examples of what a sustainable development could be.

\section{REFERENCES}

AISTARA, Guntra. 2013. "Weeds or Wisdom? Permaculture in the Eye of the Beholder on Latvian Eco-Health Farms". In Environmental Anthropology engaging Ecotopia. Bioregionalism, Permaculture and Ecovillages, ed. Joshua Lockyer and James R. Veteto. New York - Oxford: Berghahn, 113-129.

ANDREAS, Marcus and Felix WAGNER, ed. 2012. Realizing Utopia. Ecovillage Endeavours and Academic Approaches. Munich: Rachel Carson Centre Perspectives.

APPADURAI, Arjun. 2013. The Future as Cultural Fact: Essays on the Global Condition. London - New York: Verso Books.

BATES, Albert K. 2003. "Ecovillages”. In Encyclopedia of Community: From the Village to the Virtual World, ed. Karen Christensen and David Levinson. Thousand Oaks: SAGE Publications, 424-425. 
BAUMAN, Zygmunt. 2001. Voglia di comunità. Bari - Roma: Laterza.

BOYLE Paul, Keith HALFACREE and Vaughan ROBINSON. 1998. Exploring Contemporary Migration. Harlow: Longman.

CASTREJON CARDENAS, Carmen. 2007. A simple life? The symbolic significance of environmentalism in the construction of a community: case study in the ecovillage of Las Nubes in Veracruz, Mexico. MSc Thesis, University of Tromsø.

COHEN, Anthony. 1985. The Symbolic Construction of Community. London - New York: Routledge.

DAWSON, Jonathan. 2013. "From Islands to Networks: The History and Future of the Ecovillage Movement". In Environmental Anthropology engaging Ecotopia. Bioregionalism, Permaculture and Ecovillages, ed. Joshua Lockyer and James R. Veteto. New York - Oxford: Berghahn, 217-234.

EDWARDS, Andres R. 2005. The Sustainable Revolution: Portrait of a Paradigm Shift. Gabriola, BC: New Society Publishers.

ESCRIBANO, María Jesús Rivera. 2007. "Migration to rural Navarre: Questioning the experience of counterurbanisation". Tijdschrift voor Economische en Sociale Geografie, vol. 98/1:32-41. https://doi.org/10.1111/j.1467-9663.2007.00374.x

ESTEVA, Gustavo. 1992. "Development". In The Development Dictionary: a Guide to Knowledge as Power, ed. Wolfgang Sachs. London - New Jersey: Zed Books, 6-25.

EUROPEAN COMMISSION. "Sustainable Development”. http://ec.europa.eu/ environment/eussd/ (last modified June 26, 2016).

EUROPEAN UNION. “Environment”. http://europa.eu/pol/env/index_en.htm (last modified June 26, 2016).

FOX, Kathie. 2013. "Putting Permaculture Ethics to Work: Commons Thinking, Progress and Hope". In Environmental Anthropology engaging Ecotopia. Bioregionalism, Permaculture and Ecovillages, ed. Joshua Lockyer and James R. Veteto. New York - Oxford: Berghahn, 164-179.

GEN. n. d. "Community Sustainability Assessment” (CSA). http://gen.ecovillage.org/en/ node/5039 (accessed June, 2016)

GIANI, Alberto. 2011. Novelties, retro-innovation and fantasy: Torri Superiore Ecovillage as a form of resistance to the abandonment of rural marginal areas in Italy. MSc Thesis, Wageningen University.

GILMAN, Robert. 1991. "The Eco-village Challenge. The challenge of developing a community living in balanced harmony - with itself as well as nature - is tough, but attainable". IN CONTEXT, A Quarterly of Humane Sustainable Culture, vol. 29/ Living Together:10. Available at http://www.context.org/iclib/ic29/gilman1/ 
GUIDI, Rossana. 2010. Ecovillaggi: esperienze comunitarie tra utopia e realtà. $\mathrm{PhD}$ Thesis, University of Pisa.

GRASSENI, Cristina. 2014. "Seeds of Trust. Italy's Gruppi di Acquisto Solidale (Solidarity Purchase Groups)". Journal of Political Ecology, vol. 21:178-192. http://jpe.library.arizona.edu/volume_21/Grasseni.pdf

GREENBERG, Daniel. 2013. “Academia's Hidden Curriculum and Ecovillages as Campuses for Sustainability Education”. In Environmental Anthropology engaging Ecotopia. Bioregionalism, Permaculture and Ecovillages, ed. Joshua Lockyer and James R. Veteto. New York - Oxford: Berghahn, 269-284.

HALFACREE, Keith. 1995. "Talking About Rurality: Social Representations of the Rural as Expressed by Residents of Six English Parishes". Journal of Rural Studies, vol. 11/1:1-20. https://doi.org/10.1016/0743-0167(94)00039-C

HALFACREE, Keith. 2006. "From dropping out to leading on? British counter-cultural back-to-the-land in a changing rurality". Progress in Human Geography, vol. 30/3:309-336. https://doi.org/10.1191/0309132506ph609oa

HAZELIP, Emilia. 2014. Agricoltura Sinergica: le origini, l'esperienza, la pratica. Firenze: Terra Nuova Edizioni.

HERVIEU, Bertrand and Danièle LÉGER. 1983. Des communautés pour les temps difficiles: néo-ruraux ou nouveaux moines. París: Le Centurion.

HOLMGREN, David. 2002. Permaculture: Principles \& Pathways Beyond Sustainability. East Meon: Permanent Publications.

HORVADAS Tasos and George P. STAMOU. 2006. "Structural and narrative reconstruction of rural residents' representations of 'nature', 'wildlife', and 'landscape"”. Biodiversity and Conservation, vol. 15:1745-1770. https://doi. org/10.1007/s10531-004-5021-1

JACKSON, Hildur. 1998. "What is an ecovillage?”. http://www.gaia.org/gaia/resources/ articles/ (accessed June, 2016)

KASPER, Van Schyndel Debbie. 2008. "Redefining Community in the Ecovillage". Human Ecology Review, vol. 15/1:12-24. https://msuweb.montclair.edu/ franker/ EVI/EVIJournalArticles/kasper2008.pdf

LIFTIN, Karen. 2009. "Reinventing the future: The global ecovillage movement as a holistic knowledge community". In Environmental governance: power and knowledge in a local-global world, ed. Gabriela Kütting and Ronnie D. Lipschutz. London: Routledge, 124-142.

LOCKYER, Peter Joshua. 2007. Sustainability and Utopianism: An Ethnography of Cultural Critique in Contemporary Intentional Communities. $\mathrm{PhD}$ Thesis, on-line version, University of Georgia, https://getd.libs.uga.edu/pdfs/lockyer joshua_p_200708_phd.pdf (accessed June 2016) 
LOCKYER, Peter Joshua and James R. VETETO. 2008. "Environmental Anthropology Engaging Permaculture: Moving Theory and Practice Toward Sustainability". Culture, Agriculture, Food and Environment, vol. 30/1-2:47-58. https://doi. org/10.1111/j.1556-486X.2008.00007.X

LOCKYER, Peter Joshua and James R. VETETO, ed. 2013. Environmental Anthropology engaging Ecotopia. Bioregionalism, Permaculture and Ecovillages. New YorkOxford: Berghahn.

MAFFI, Luisa. 2005. "Linguistic, Cultural, and Biological Diversity". Annual Review of Anthropology, vol. 29:599-617. https://10.1146/annurev.anthro.34.081804.120437

MOLLISON, Bill and Reny Mia SLAY. 2007. Introduzione alla Permacultura. Firenze: Terra Nuova Edizioni.

NOGUE' I FONT, Joan. 1988. "El Fenomeno Neorrural”. Agricultura y Sociedad, vol. 47/Abril-Junio:145-175. http://www.mapama.gob.es/ministerio/pags/biblioteca/ revistas/pdf_ays/a047_06.pdf

OLIVARES, Manuel. 2009. Comuni, comunità, ecovillaggi. London: Viverealtrimenti.

OSBALDISTON, Nicholas. 2012. Seeking Authenticity in place, culture, and the self. The great urban escape. Basingstoke: Palgrave MacMillan.

PEARCE, David W. and Giles D. ATKINSON. 1993. "Capital theory and the measurement of sustainable development: an indicator of "weak" sustainability". Ecological Economics, vol. 8:103-108. https://doi.org/10.1016/0921-8009(93)90039-9

RAPPORT Nigel and Joanna OVERING. 2000. Social and Cultural Anthropology - The Key Concepts. London and New York: Routledge.

SVENSSON, Karen. 2002. "What is an ecovillage?". In Ecovillage Living: Restoring the Earth and Her People, coauthor Hildur Jackson. Totnes: Green Books Ltd, 10-12.

UNESCO. 2002. Universal Declaration on Cultural Diversity. http://unesdoc.unesco.org/ images/0012/001271/127162e.pdf (accessed October 2016).

WHITEFIELD, Patrick. 2012. Permacultura per Tutti. Oltre l'agricoltura biologica, per curare la Terra e guarire il Pianeta. Firenze: Terra Nuova Edizioni.

WIGHT, Alan R. 2008. “We are Nature”: Exploring Ecovillagers'Perceptions of Nature and Use of Technology. MA Thesis, University of Cincinnati. 
Martina Losardo

\section{"NOVI NAČINI ŽIVLJENJA, STARI KAO I SVIJET": DOBRA PRAKSA I ODRŽIVOST NA PRIMJERU TALIJANSKE MREŽE EKOSELA}

Pokret za ekosela međunarodna je mreža ciljanih zajednica usredotočena na društvenu, ekonomsku i ekološku održivost. Za razliku od ostalih ekoloških pokreta, njihova borba za postizanje održivog načina življenja uključuje i napore za unapređenje vlastite životne sredine što se temelji na načelu da su ljudska bića dio prirode kao i sva druga živa bića. U postizanju toga cilja često obnavljaju tradicijska znanja i prakse koje vuku korijene iz pretkapitalističke ruralne prošlosti jer vjeruju da su u to vrijeme odnosi s onim Drugim (kako s drugim zajednicama tako i s prirodom) bili bolji nego što su u suvremenom industrijaliziranom društvu.

Ključne riječi: ekosela, zajednica, održivost, permakultura, ruralna prošlost, neoruralizam, priroda

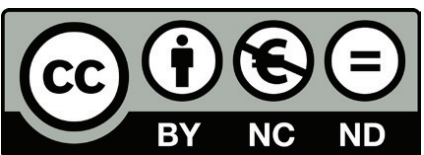

Articles published in this journal are Open Access and can be distributed under the terms and conditions of the Creative Commons license Attribution-NonCommercial-NoDerivatives 4.0 (http://creativecommons.org/licenses/by-nc-nd/4.0/) 